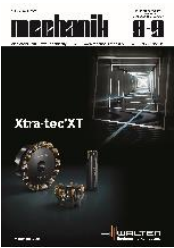

How to cite this article:

Authors: Marcin Podsiadło, Lucyna Jaworska, Piotr Klimczyk

Title of article: "Direct brazing of diamond to the tool body - brazing solders and methods"

Mechanik, No. 8-9 (2019)

DOI: https://doi.org/10.17814/mechanik.2019.8-9.63

\title{
Direct brazing of diamond to the tool body - brazing binders and methods
}

\author{
MARCIN PODSIADEO \\ LUCYNA JAWORSKA \\ PIOTR KLIMCZYK*
}

\begin{abstract}
Mgr inż. Marcin Podsiadło, marcin.podsiadlo@ios.krakow.pl, https://orcid.org/0000-0002-3962-6268 - Sieć Badawcza Łukasiewicz Instytut Zaawansowanych Technologii Wytwarzania; Wydział Metali Nieżelaznych Akademii Górniczo-Hutniczej im. S. Staszica, Kraków, Polska

Prof. dr hab. inż. Lucyna Jaworska, lucyna.jaworska@ios.krakow.pl, https://orcid.org/0000-0002-1240-2694 - Sieć Badawcza Łukasiewicz - Instytut Zaawansowanych Technologii Wytwarzania; Wydział Metali Nieżelaznych Akademii Górniczo-Hutniczej im. S. Staszica, Kraków, Polska

Dr hab. inż. Piotr Klimczyk, https://orcid.org/0000-0002-8060-1388 - Sieć Badawcza Łukasiewicz - Instytut Zaawansowanych Technologii Wytwarzania, Kraków, Polska
\end{abstract}

The article presents the problem of direct brazing of diamond to the tool body. The greatest threats to the brazing joint were discussed: stress and poor wettability. Methods for producing polycrystalline diamond blanks by various methods were presented. The metal alloys (solders) with a silver, nickel and copper matrix that is used for brazing diamonds were described. The most commonly used brazing methods (resistance, induction, laser and infrared) were discussed.

KEYWORDS: brazing, diamond, PCD, ceramics, tools

\section{Introduction}

Increasing the strength of metal-ceramics joints is the goal of many scientific studies. Such joints work in difficult conditions - they are exposed to high and low temperatures and are subject to variable mechanical and thermal loads. The most dangerous is large difference in internal stress. In ceramics, these stresses can add up to tensile operating stresses, which sometimes leads to exceeding the strength of the entire joint and, as a result, to its destruction [1].

Magnitude of internal stress in ceramic-metal joints is influenced by:

- linear expansion coefficients of ceramics and metal,

- longitudinal elasticity modules and form deformation module,

- yield strength of metal, depending on the temperature,

- heat conductivity coefficient for joint elements,

- geometrical factors such as shape and dimensions of welded elements [2, 3].

Level of stress in the joint can be reduced by appropriate selection of all its elements, including ensuring that they have similar values of above listed properties.

The reason for inadequate joint properties, e.g. leaks or low strength, is poor wettability between solder alloys and ceramic surface. Typical metal brazing temperature for ceramics is in the range of $470 \div 1190^{\circ} \mathrm{C}$. Of course, the decisive parameters for the brazing process are the heating rate, brazing temperature, type of atmosphere, holding time at brazing temperature and cooling rate.

Tight and durable joint between ceramics and metal can be achieved by three methods:

- by applying metal coatings to a ceramic substrate to obtain a low-energy metal-metal interface,

- by decomposition (dissociation) and diffusion of ceramic material in the solder using the dissolution of ceramic components in the solder,

- by using active metals and creating new solid phases, which are beneficial for the joint [4]. 


\section{Diamond materials and brazing of polycrystalline diamond blades on a cemented carbide substrate}

A diamond is a crystalline form of carbon with a regular structure. It is the hardest of all known materials. The limitation of natural diamond use is the lack of natural crystals in the full size range. Currently, natural diamond accounts for only $10 \%$ of technical diamonds - the remainder of the demand is covered by synthetic diamonds.

Synthetic diamond was first obtained by allotropic transformation of graphite in the presence of catalysts, under high pressure and high temperature. In the 1970s, polycrystalline diamond was obtained by highpressure sintering, which was used in the production of machining tools, for building stone processing, in drilling and as eyelets in drawing dies intended for the production of non-ferrous metal wires [5]. Currently, PCD tools are used to process non-ferrous materials (e.g. aluminum alloys, titanium alloys, plastics, fiberreinforced polymers, composites, ceramics).

In the 80s, the low-pressure concept for the production of synthetic diamond by chemical crystallization from the gaseous phase CVD (chemical vapor deposition) was implemented. This technique allows the diamond to be applied to large areas. In the CVD method, diamond is synthesized from carbon-abundant gases, at conditions close to atmospheric pressure, without any additives (e.g. cobalt binding phase). Diamond obtained by CVD methods is characterized by high chemical purity and correctness of crystallographic structure. It has high thermal conductivity (up to six times greater than copper), which is also a desirable property of cutting tool blades. The abrasion resistance of such a diamond is higher compared to polycrystalline materials obtained under high pressure. Most often, a polycrystalline CVD diamond is applied in the form of coatings up to $0.5 \mathrm{~mm}$ thick. The weakness of these materials - compared to diamonds obtained under high pressure - is greater brittleness. Polycrystalline diamond with a cobalt binding phase (up to $10 \%$ by volume) is obtained in the form of thin layers, 0.3 to $1.5 \mathrm{~mm}$ thick, sintered in the same process with a WCCo cemented carbide washer. In this way, in one sintering process, a two-layer sinter is formed, which is connected to the tool body (e.g. cutting plate) through a cemented carbide layer using silver and copper based solder, often containing indium and titanium.

Companies producing commercial polycrystalline diamond materials emphasize that the temperature of brazing process should not exceed $730^{\circ} \mathrm{C}$, and the time of high temperature holding must be minimized. For brazing, solders with a brazing temperature of $600 \div 700^{\circ} \mathrm{C}$ are used. Attention is paid to the tool body, the thermal expansion coefficient of which should not significantly differ from thermal expansion coefficient of the PCD and cemented carbide backing layer. If the difference in thermal expansion coefficients is large, there is a risk of thermal stress of the second type, and relaxation of these stress may result in cracks. After brazing, air cooling is recommended (cooling in liquids is not recommended).

Induction and ultrasonic devices are often used for brazing, and most often lasers [6].

\section{Diamond solder alloys}

Diamond (polycrystalline, monocrystalline, diamond powders and diamond in the form of thick CVD layers) is non-wettable by most solders and difficult to combine with conventional solders due to their chemical composition. During the brazing process, solutions and metastable carbides ( $\mathrm{Co}, \mathrm{Ni}, \mathrm{Fe}$ ) are formed at elevated temperature, and among the elements ( $\mathrm{Ti}, \mathrm{Zr}, \mathrm{Hf}, \mathrm{Nb}, \mathrm{Mo}, \mathrm{Mn}, \mathrm{Si}$ ) - stable carbides. Diamond materials have much higher modulus of elasticity than metals. The mismatch of the Young's modulus of the tool body material and the diamond material may result in a high level of residual stress.

Residual thermal stress is another serious problem arising from a mismatch between thermal expansion coefficients of the diamond and WC-Co substrate or diamond and the metal body of the tool. Metal of the tool body and solder alloy shrinks more than the diamond material during cooling after the brazing process. Residual thermal stresses can cause interphase cracks and then reduce the shear strength of brazed components.

One of the most important issues regarding brazing a diamond is the selection of a solder with an appropriate melting point not exceeding the graphitization temperature of the diamond. Diamond is a metastable form - in atmospheric conditions - of carbon, while graphite is stable. Supplying additional energy to the diamond, e.g. in the form of heat, causes its allotropic transformation into graphite. For synthetic diamond, the temperature of graphitization in air is (depending on the catalysts used in the metal synthesis process) about $700^{\circ} \mathrm{C}$, and for single crystals - above $1000^{\circ} \mathrm{C}$. For the silver-copper system (at $28 \%$ copper content), the melting point of eutectics is $779^{\circ} \mathrm{C}$. These alloys form the basis of diamond solders. The addition of such metals as zinc, cadmium and tin lowers the melting point of the solder alloy, which has a positive effect on reducing the diamond graphitization process. The addition of a few percent titanium improves the wetting 
of the solder alloy to the diamond. As the titanium content increases, the strength of the joints decreases due to the increase in the thickness of the TiC layer and other intermetallic phases. The amount of titanium introduced into this solder should not exceed $4 \%$ by weight [8].

A high-temperature nickel-based solder alloy containing elements such as chromium, boron, silicon, titanium and iron has also been used to braze diamond to metal bodies of cutting tools. Silicon and chromium carbides are formed in the brazing zone. Chromium has been shown to improve diamond wettability by solder alloys, however, compared to copper and silver matrix solders, it has higher melting point [9].

A composition containing $20 \% \mathrm{Sn}$ and $10 \%$ Ti was selected as the optimal composition of the copper matrix solder intended for brazing diamond in cutting tools. The brazing temperature for this alloy is $960^{\circ} \mathrm{C}$. It has better strength and erosion resistance compared to Ag-Cu alloys and lower melting point compared to nickelbased alloys [10].

In the literature on commercial solders, examples of brazing of carbide substrates with a diamond layer sintered with the substrate in the same process are most often given. In this case, therefore, there is no diamond brazing process, but cemented carbide brazing to the tool body occurs. Melting point of commercial brazing solders is in the range of $660-1000^{\circ} \mathrm{C}$, with slow heating and cooling in the range of $700-1000^{\circ} \mathrm{C}$ [11]. The material withstand time above $700^{\circ} \mathrm{C}$ is also limited.

Avoiding the graphitization process and properly filling the joint with solder material due to good wettability are not the only challenges in the diamond brazing process. The joint must have adequate strength. The atmosphere of the process is also an important parameter of the diamond brazing process. Diamond brazing can be carried out in an inert $(\mathrm{Ar}, \mathrm{N} 2, \mathrm{He})$, reducing $\left(\mathrm{H}_{2}\right)$ or high vacuum atmosphere. The oxygen content in the shielding gas should be less than $1 \mathrm{ppm}$. The most commonly used are argon or a mixture of argon with 5\% hydrogen. Solder for diamond brazing is available in the form of a paste or foil. From an economic point of view, pastes are less efficient than films, and in addition, they must be heated much more slowly, in a vacuum, because the solder must be removed in the first phase. Rapid degassing of the paste in the solder results in poor joint quality (porosity). Pastes are easier to spread. In the case of pastes, induction or resistance heating should not be used, as these are processes that cause rapid heating [11].

\section{Process of brazing diamond to tool bodies}

The processes of direct brazing of diamond materials (without the intermediate layer in the form of sintered carbide) are one or two stages. Single-stage processes are carried out using an alloy that contains metals active towards the diamond, moistens its surface and forms a strong bond with carbon atoms. The content of active metals in the solder should, however, be limited to $1 \div 10 \%$ by weight. [12].

The second method involves two-stage brazing processes, in which the diamond is coated with a metal layer and conventional solder used for joining metals can be used for brazing. In contrast to oxide or nitride ceramics, very active elements such as hafnium, zirconium and titanium are not required for metal coatings. Studies have confirmed the effectiveness of such elements as chromium or silicon, which in turn are easier to use due to the lower affinity towards oxygen and thus lower vulnerability for oxidation [13].

An example of one-step brazing of diamond grain on a steel substrate is brazing with a Ni-Cr-B-Si brazing alloy. The process was carried out with a laser beam in an argon atmosphere. The Ni-Cr-B-Si alloy in the laser brazing process showed good wetting of diamond grains and steel. In the area of the interface between diamond grains and brazing solder, chromium appeared on the surface of the diamond grain in the form of two carbides, i.e. Cr7C3 and $\mathrm{Cr} 3 \mathrm{C} 2$, which ensured strong bonding of the diamond with the solder. A good joint was also obtained between the steel substrate and the solder alloy [14].

Joints between CVD diamond (thick diamond layers, obtained by chemical vapor deposition technique) and cemented carbide are often studied due to the wide range of applications. Active brazing metals based on silver and copper are used for brazing. Solders should contain up to $1.25 \mathrm{wt}$. active ingredient, e.g. Ti. With this amount of active ingredient, the solder showed adequate wettability - a strong bond with the carbide substrate was obtained. For the brazing process using AgCuInTi1.25 solder, good wetting and a limited reaction area between the diamond, solder and cemented carbide substrate were obtained. Meanwhile, at higher concentrations of active ingredients, e.g. $3 \mathrm{wt}$. Ti, greater reaction range and adverse effect on the mechanical properties of the joint were observed [15].

\section{Diamond brazing methods}

Different sources of heat are used in diamond brazing processes: flame, infrared, electric induction, immersion, laser and resistance. 


\section{Infrared brazing}

High intensity quartz lamps are used for infrared brazing to generate electromagnetic radiation wavelengths longer than visible spectrum. This radiation is absorbed by the brazed part. The brazed part can be placed in a special retort or container containing shielding gas. Infrared brazing has been developed for brazing honeycomb panels. The key task in this process is temperature control.

\section{Resistive brazing}

Resistive brazing is a process, in which the heat generated in the solder joint is the result of electrical resistance. Heat is generated in brazed components, in electrodes that contact components, or in both systems. Resistive heating is very local and fast. It is characterized by a temperature gradient, therefore small volume components are brazed using this method. Resistive brazing is the most energy-saving and the least expensive.

\section{Brazing in a resistance furnace}

Brazing in a resistance furnace is the process, in which the heat source for brazing is heat radiation. Electricity is supplied to the heating elements of the furnace, made of e.g. graphite, tantalum or molybdenum. The heat from the element is then radiated towards the heated part. The resistance furnace can be used to control temperature, vacuum and protective atmosphere with high accuracy. These furnaces are mainly used when brazing pastes are used. It should be remembered that the removal of the solder has a detrimental effect on the furnace heating elements and its lining. Maintenance and operating costs are relatively high. This is due to the fact that the retaining elements should be replaced periodically. The frequency of replacement depends on the operating temperature, operating hours and process cleanliness.

\section{Induction brazing}

Induction brazing in its basic configuration consists in the fact that the semiconductor RF power supply sends alternating current through a copper coil, in which the brazing part is placed inside. The coil serves as a primary transformer, and the heated part becomes a secondary circuit. When the metal part is placed in the induction coil and in the magnetic field, the circulating eddy currents are induced within the brazed part. Eddy currents produce precise and localized heat, without any direct contact between the part being soldered and the coil. For sensitive brazing operations, such as brazing diamonds, the induction system can be equipped with an optical pyrometer that facilitates the closed-loop temperature control. By properly selecting the induction heating supply, temperature controller and optical pyrometer, temperature control at $\pm 2^{\circ} \mathrm{C}$ is ensured [11].

\section{Furnace induction brazing}

Furnace induction brazing is a process, in which the graphite susceptor is heated by induction. The susceptor then emits heat to the part to be brazed. Unlike resistive furnaces, induction furnaces of the size typically used for brazing diamonds do not have many zones. Temperature uniformity is achieved due to the construction of the coil and insulation. As with resistive furnaces, induction furnaces may have protective atmospheres, including inert gas or high vacuum atmospheres, or their combination.

\section{Laser brazing}

Laser brazing is definitely the most advantageous compared to other methods. In this case, brazing time is several seconds, while brazing with other methods takes up to several hours [16]. Different types of lasers are used for laser brazing, with different wavelengths, e.g. $\mathrm{CO}_{2}$ or Nd:YAG laser. Wavelengths are characterized by different absorption coefficients and thus different temperature and temperature distribution in the material affected by the laser beam [17]. Material absorption as a function of laser wavelength and temperature (in the range from room temperature to the point of material evaporation) significantly affects the efficiency of the laser machining process. Forecasts of the laser machining process using simplified or sophisticated models, require knowledge of material absorption.

Due to the poor brazability of titanium alloys, which are sometimes used to make tool bodies, gluing and additionally mechanical attachment are used to fix the blade segments to reduce weight [18]. 


\section{Monolithic diamonds and their brazing}

In the case of sintered polycrystalline diamond, a cemented carbide substrate is most often used, and brazing involves welding the carbide with the tool body. The reason for using brazing through a carbide intermediate layer in commercial solutions is low resistance of polycrystalline diamond to conversion into graphite.

Polycrystalline diamond materials without cemented carbide substrates have been obtained for many years in the Łukasiewicz Research Network - Institute of Advanced Manufacturing Technologies in Krakow. The main goal of the research is to obtain materials with increased resistance to high temperatures - which is achieved by limiting the contribution of the cobalt phase in sinters $[19,20]$.

The first example of brazing these materials was the metallization of sintered diamond containing $5 \% \mathrm{Ti}$ as the binding phase (after sintering the material consisted of diamond and TiC). The sintered metal was metallized by PVD (physical vapor deposition) method with pure titanium, and then induction brazed using $\mathrm{Cu}$-Ag solder [21]. These materials also have good electrical conductivity, although they lack a metal phase, because ceramics were used instead of cobalt. The process of brazing diamond materials with a binding phase in the form of titanium silicon carbide Ti3SiC2 (in the amount of $15 \%$ by weight) with the addition of nanometric powder TiCN (in the amount of $5 \%$ by weight) was carried out using B-Ag70.5Cu26.5Ti solder (ISO 3677). For this solder, the manufacturer recommends brazing temperatures of ceramic materials above $850^{\circ} \mathrm{C}$. Under vacuum brazing, a temperature of not more than $900^{\circ} \mathrm{C}$ is recommended. The brazing solder was purchased in the form of $0.2 \mathrm{~mm}$ thick ribbons and the elements corresponding to the geometry of the diamond blade were cut out from it. Two brazing temperatures were used: $865^{\circ} \mathrm{C}$ and $900^{\circ} \mathrm{C}$. The brazing process was carried out in a Nabertherm VHT 08-20 vacuum furnace. The heating rate was $100^{\circ} \mathrm{C} / \mathrm{min}$, while the holding time at maximum temperature was $30 \mathrm{~min}$. Better results were obtained for higher brazing temperature - the joint made had less porosity. Regardless of the brazing temperature, no differences were found in the hardness of the brazed material. In both of the presented cases, the joint between the monocrystalline diamond and brazing solder consists in the reaction of carbon from the diamond with active titanium, which is in the solder or coating. As a result of the reaction, titanium carbide is formed. Considering that the component of the diamond-binding phase is titanium carbide, the materials exhibit high coherence with each other, resulting in a lack of stress and any discontinuities in the connection zone. New materials containing other ceramic binding phases require different brazing solutions.

\section{REFERENCES}

[1] Kaliński D. „Opracowanie spoiwa kompozytowego do spajania ceramiki korundowej z metalami”. Prace ITME. Zeszyt 53. Warszawa: ITME, 1999.

[2] Seo K., Kusuka M., Nogato F., Teresaki T., Nakao Y., Saida K. "Study of thermal stress at ceramic-metal joint". JSME International Journal. Series 1. 2 (1990): 33.

[3] Suganuma K., Okamoto T., Koizumi M., Kamachi K. "Influence of shape and size on residual stress in ceramic/metal joining". Journal of Materials Science. 22, 10 (1987): 3561-3565.

[4] Nicolas M.G., Peteves S.D. "Reactive joining: Chemical efects on the formation and properties of brazed and diffusion bonded interfaces". Scripta Metallurgica et Materialia. 31, 8 (1994): 1091-1096.

[5] Sigalas I., Caveney R.J. "Diamond Materials and Their Applications". Handbook of Ceramic Hard Materials (ed.: Ralf Riedel). Weinhheim: Wiley-VCH, 2000: 481.

[6] http//www.e6.com. "Diamond Tool Materials for Metalworking: Tool Fabrication Troubleshooting".

[7] Jaworska L. „Diament - Otrzymywanie i zastosowanie w obróbce skrawaniem”. Warszawa: WNT, 2008.

[8] Chen Y., Hong J.X., Fu Y.C., Su H.H. "Effect of Ti addition on shear strength of brazing diamond and Ag based filler alloy". Key Engineering Materials. 416 (2009): 264-268.

[9] Tillmann W., Wojarski L., Lehmert B. "Investigation of mechanical and metallurgical properties of brazed ceramic and cemented carbide joints". IIW 2010 - International Conference on Advances in Welding Science \& Technology for Construction, Energy \& Transportation, Istanbul. (2010): 337-341.

[10] Klotz U.E., Liu C., Khalid F.A., Elsener H.R. "Influence of brazing parameters and alloy composition on interface morphology of brazed diamond". Materials Science and Engineering: A. 495, 1-2 (2008): 265-270.

[11] Skewes S. "Equipment Solutions for the Brazing of Diamond Tools". http://www.ghia.com/pdf/brazing-diamond-tools.pdf.

[12] Naidich Y.V., Umanskii V.P., Lavrinenko L.A. "Strength of the Diamond-Metal Interface and Brazing of Diamonds". Cambridge (UK): Cambridge International Science Publishing Ltd, 2007. 
[13] Tillmann W., Osmanda A.M. "Production of diamond tools by brazing". Materials Science Forum. 502 (2005): 425-430.

[14] Jiang Z., Zhang C. "Analysis on microstructure of laser brazing diamond grits with a Ni-based filler alloy". Advanced Materials Research. 97-101 (2010): 3879-3883.

[15] Tillmann W., Osmanda A.M., Yurchenko S. "Investigations of contact angles of active brazing fillers on diamond-layers by optical 3D-microscopy". Proc 4th Int Brazing \& Soldering Conference, Florida (USA), 2009.

[16] Haferkamp H., Bach F.W., von Alvesleben F., Mai T., Kreutzburg K. "Laserstrahllöten von MetallKeramik-Verbindungen". Schweissen Schneiden. 48 (1996): 853-859.

[17] Zhang Z., Modest M.F. „Temperature-dependent absorptances of ceramics for Nd:YAG and $\mathrm{CO}_{2}$ laser processing applications". Journal of Heat Transfer, 120, 2 (1998): 322-327.

[18] Cichosz P., Kuzinovski M., Tomov M. „Narzędzia skrawające z materiałów supertwardych. Cz. I. Ostrza diamentowe". Mechanik. 90, 8-9 (2017): 660-662, 664-668.

[19] Cygan S., Jaworska L., Putyra P., Ratuszek W., Cyboroń J., Klimczyk P. “Thermal stability and coefficient of friction of the diamond composites with the titanium compound bonding phase". Journal of Materials Engineering and Performance. 26, 6 (2017): 2593-2598.

[20] Jaworska L., Klimczyk P., Szutkowska M., Putyra P., Sitarz M., Cygan S., Rutkowski P. "Thermal resistance of PCD materials with borides bonding phase". Journal of Superhard Materials. 37 , 3 (2015): 155-165.

[21] Jaworska L. „Dobór metalicznej fazy wiq̨żacej i sposobu jej wprowadzania do kompozytu diamentowometalowego". Prace IOS, nr 77. Kraków: IOS, 1994.

[22] Jaworska L., Rozmus M., Laszkiewicz-Łukasik J., Wyżga P., Podsiadło M., Czechowski K. „Wykonanie płytek skrawających z monolitycznego spieku diamentowego". Mechanik. 8-9 (2012): 39-46 (CD). 